\title{
Morphological Alterations and G0/G1 Cell Cycle Arrest Induced by Curcumin in Human SK-MEL-37 Melanoma Cells
}

\author{
Marcella Lemos Brettas Carneiro ${ }^{1}$, Elaine Paulucio Porfírio ${ }^{2}$, Andréia Hanada Otake ${ }^{3}$, \\ Roger Chammas ${ }^{3}$, Sônia Nair Báo ${ }^{2}$ and Lidia Andreu Guillo ${ }^{{ }^{*}}$ \\ ${ }^{1}$ Laboratório de Bioquímica Celular; Instituto de Ciências Biológicas; Universidade Federal de Goiás; 74001-970; \\ Goiânia - GO - Brasil. ${ }^{2}$ Laboratório de Microscopia de Elétron; Departamento de Biologia Celular; Universidade \\ de Brasília; 70910-900; Brasília - DF - Brasil. ${ }^{3}$ Laboratório de Oncologia Experimental; Faculdade de Medicina; \\ Universidade de São Paulo; 01246-903; São Paulo - SP - Brasil
}

\begin{abstract}
The aim of this work was to study the effect of curcumin on cell cycle in the human SK-MEL-37 melanoma cell line. In addition, morphological and structural analyses were also performed. Flow cytometric analysis showed a G0/G1 arrest at $5 \mu \mathrm{M}$ after $24 \mathrm{~h}$ exposure and a concentration-dependent increase in the proportion of sub-GO hypodiploid cells. Typical apoptotic events were also observed by the fluorescence microscopy, transmission and scanning electronic microscopy. Loss of mitochondrial membrane potential was not detected. Results suggested that curcumin could arrest human melanoma cells at G0/G1 phase and induce a mitochondrial-independent apoptotic pathway.
\end{abstract}

Key words: curcumin, melanoma cells, apoptosis, cell cycle

\section{INTRODUCTION}

Melanoma is a cancer that arises from melanocytes, specialized pigmented cells found predominantly in the skin (Gray-Schopfer et al., 2007). This tumor is the main cause of death in patients with skin cancers whose incidence has been steadily increasing worldwide, resulting in a serious public health problem (Markovic et al., 2007). Indeed, malignant melanoma cells are notoriously resistant to radiation and chemotherapy (Zheng et al., 2004). Due to the low effectiveness of treatments employed currently for melanoma, the development of new agents that are less toxic and do not unchain chemoresistance becomes primordial.

Throughout the medical history, plant products have been shown to be valuable sources of novel anti-cancer drugs (Mans et al., 2000). The curcumin (diferuloylmethane) is a phenolic compound derived from rhizome of the turmeric (Curcuma longa Linn.), a perennial plant from the Zingiberaceae family that is widely cultivated in the tropical regions of Asia, most extensively in India, and Latin America (Araújo et al., 2001). The powdered dry rhizome of $C$. longa has been extensively used as dietary spice and coloring agent in Asian cooking and also as an herbal folk

*Author for correspondence: lidia.guillo@gmail.com 
medicine to treat the wounds, inflammation and tumors. So, curcumin has attracted considerable interest of the scientific community in the last three decades (Sharma et al., 2005). A large variety of pharmacological properties, including antiinflammatory, anti-oxidant and anti-cancer has been demonstrated in preclinical animal and pilot human studies. Moreover, curcumin can be considered pharmacologically safe, since is being consumed daily for centuries in Asian countries and has not been shown to cause any toxicity in humans (Maheswari et al., 2006; Thangapazhan et al., 2006). However, large-scale chemopreventive trials need to be performed to ensure the safety of curcumin to human health.

In recent years, cell cycle arrest and apoptosis induction have gained wide attention as a possible way of eliminating the neoplasic cells. Curcumin has been shown to inhibit the cell growth and induce apoptosis in several tumor cell types, including murine and human melanoma cell lines (Chen et al, 1998; Bush et al., 2001; Aggarwal et al., 2003; Odot et al., 2004; Zheng et al., 2004; Uddin et al., 2005; Shi et al., 2006; Su et al., 2006). However, as pointed above, melanoma may develop resistance to chemotherapy and up to now there have been no reports evaluating the effect of curcumin on human melanoma cell lines resistant to chemotherapeutic agents. In the present study, SK-MEL 37 human melanoma cells treated with curcumin were analyzed by flow cytometry, transmission and scanning electron microscopy, and fluorescence microscopy. These cells had been demonstrated to be resistant to doxorubicin and cisplatin in culture and sensitive to curcumin treatment openning the possibilities of therapeutic applications of curcumin in chemoresistant solid tumors as melanoma. Studies on the identification of possible molecular targets and more clinical trials in patients with melanoma could make possible the clinical use of curcumin as a chemotherapeutic safe agent.

\section{MATERIALS AND METHODS}

\section{Reagents}

Eagle's modified medium (MEM) was purchased from Sigma (St. Louis, MO, USA). Fetal bovine serum (FBS) was from Cultilab (Brazil). Curcumin (diferuloylmethane, 90\% purity) was purchased from Fluka (USA). Propidium iodide
(PI) was purchased from Invitrogen (USA). $\mathrm{JC}_{1}$ $\left(5,5, \quad 6,6^{\prime} \quad\right.$ - tetrachloro-1, $1^{\prime}, \quad 3,3^{\prime}$ tetraethylbenzimidazolyl carbocyanine iodide was purchased from Molecular Probes (USA). DAPI (4', 6-diamidino-2-phenylindole) was purchased from Sigma. Curcumin solutions were made 200fold concentrated in ethanol to keep final ethanol concentration below $0.5 \%$ in all the experiments.

\section{Cell culture conditions}

The human melanoma cell line SK-MEL-37 established from the metastatic melanoma nodules was generously donated by Dr. L. J. Old (Memorial Sloan-Kettering Cancer Center, N. Y., USA). Cells were grown in $25 \mathrm{~cm}^{2}$ tissue-culture flasks and maintained in modified Eagle's medium (MEM) supplemented with $10 \%$ (v/v) fetal bovine serum (FBS), $100 \mathrm{U} / \mathrm{mL}$ penicillin and $100 \mu \mathrm{g} / \mathrm{mL}$ streptomycin (Gibco BRL) in a humidified atmosphere containing $5 \% \mathrm{CO}_{2}$ at $37^{\circ} \mathrm{C}$.

\section{Cell cycle analysis}

Previous studies from this laboratory have shown relevant in vitro antiproliferative activity at curcumin concentrations as low as $20 \mu \mathrm{M}$ (Rabelo et al, 2002). The DNA content and cell cycle distribution of melanoma cells treated with the curcumin were determined by flow cytometry. Exponentially growing cells were plated on culture dishes (100 mm diameter) at a seeding density of 3 $\mathrm{x} 10^{5}$ cells $/ \mathrm{mL}$. Twenty four hours after, cells were treated with different concentrations of curcumin $(0,5,10,15$ and $20 \mu \mathrm{M})$ and incubated for a further $24 \mathrm{~h}$. They were harvested and collected by centrifugation, washed twice in phosphate buffered saline (PBS, pH 7.2) and fixed with $70 \%$ cold absolute ethanol and kept at $-20^{\circ} \mathrm{C}$ until analysis. Just before the cell cycle determination, cells were centrifuged gently (50 x g for $5 \mathrm{~min}$ ) and stained with $200 \mu \mathrm{L}$ of propidium iodide (PI) solution: (200 $\mu \mathrm{g} / \mathrm{mL}$ RNAse (Sigma), $20 \mu \mathrm{g} / \mathrm{mL}$ de PI and $0.1 \%$ Triton X-100 (Sigma) in PBS) and incubated at $37^{\circ} \mathrm{C}$ for $30 \mathrm{~min}$. Ten thousand events were acquired in a flow cytometer (FACScan Becton Dickinson, Frankilin Lakes, New Jersey, USA) using a $488 \mathrm{~nm}$ argon laser and the data were analyzed using software CellQuest ${ }^{\mathrm{TM}}$.

\section{Fluorescence microscopy}

Cells $\left(5 \times 10^{4} /\right.$ well) were plated in a polystyrene 6 well-plate (Nunc Brand Products, USA) containing sterile round glass coverslips and kept under 
culture conditions. After curcumin treatments, cells were incubated with $20 \mu \mathrm{M}$ of $\mathrm{JC}_{1}$, diluted in MEM with $10 \%$ FBS at a 1:200 ratio, during 15 minutes at $37^{\circ} \mathrm{C}$. Then the cells were washed two times in PBS and $1 \mu \mathrm{M}$ DAPI was added and further incubated for 30 minutes in the dark. Cells were washed two times with PBS and coverslips were mounted onto glass slides with glycerol and kept in the dark again. Cells were examined and photographed in a NIKON E6000 Eclipse fluorescence microscope.

\section{Transmission electron microscopy (TEM)}

For TEM analysis, cells $\left(5 \times 10^{4}\right)$ were seeded on culture dishes (100 mm diameter) and treated with $5,10,15$ and $20 \mu \mathrm{M}$ curcumin. After collection by centrifugation, cells were fixed in Karnovsky's solution $\quad(2.5 \% \quad$ glutaraldehyde, $\quad 4 \%$ paraformaldehyde, $5 \mathrm{mM} \mathrm{CaCl} 2,3 \%$ sucrose, buffered in $0.1 \mathrm{M}$ sodium cacodylate, at $\mathrm{pH}$ 7.2) for $1 \mathrm{~h}$. After fixation, cells were rinsed in the same buffer, and postfixed in $1 \%$ osmium tetroxide, $0.8 \%$ potassium ferricyanide, and $5 \mathrm{mM}$ $\mathrm{CaCl}_{2}$ in $0.1 \mathrm{M}$ sodium cacodylate buffer. The material was dehydrated in a graded acetone series (30-100\%) and embedded in Spurr resin. Ultrathin sections were stained with uranyl acetate and lead citrate and observed in a Jeol ${ }^{\circledR} 1011$ transmission electron microscope at $80 \mathrm{kV}$.

\section{Scanning electron microscopy (SEM)}

Cells in suspension were attached to poly-L-lysinecoated coverslips and immersed in fixative solution. Fixation was carried out at room temperature for $1 \mathrm{~h}$ in Karnovsky's solution. Primary fixation was followed by rinsing in the same buffer and postfixation for $30 \mathrm{~min}$ in osmium-potassium ferricyanide solution. After fixation, the coverslips with adherent cells were processed through a graded ethanol series, critical point dried in $\mathrm{CO}_{2}$, covered with a layer of gold and observed in a JEOL JSM 840 scanning electron microscope, at an accelerating voltage of $5.0 \mathrm{kV}$.

\section{Statistics}

Each curcumin concentration was assayed in triplicate and experiments were conducted four different sets. Graphical data points represent arithmetic means \pm standard deviation (SD) of the four independent experiments. The significance was determined by ANOVA and Bonferroni's post test. Probability values (p) of 0.05 or less were considered as significant.

\section{RESULTS}

\section{Effect of curcumin on cell cycle distribution of SK-MEL-37 cells}

To determine whether the growth inhibition was attributable to cell-cycle arrest and/or apoptosis, flow cytometric analysis was performed. Ten thousands cells were recorded and results presented as percentage ( \pm standard error) of cells in each phase (Figs. 1 and 2). The percentage of sub-G0 populations was: $2.36 \%( \pm 0.22), 3.53 \%$ $( \pm 0.49), 7.52 \%( \pm 1.60), 11.1 \%( \pm 1.81)$ and $18.43 \%( \pm 2.12)$, after a $24 \mathrm{~h}$ treatment with 0,5 , 10,15 and $20 \mu \mathrm{M}$ curcumin, respectively. There was no obvious increase of sub-G0 populations after treatment with $0.5 \%$ of pure ethanol (data not shown).

Flow cytometry showed a significant increase in the percentage of cells in G0/G1 $(\mathrm{p}<0.001)$ at 5 $\mu \mathrm{M}$ curcumin (Fig. 2A) followed by a significant SG2M decrease $(\mathrm{p}<0.001)$ in comparison to control cells (Fig. 2B). This indicated that at $5 \mu \mathrm{M}$ concentration, curcumin induced a G0/G1 cell cycle arrest. For concentrations above $5 \mu \mathrm{M}$, cells underwent apoptosis which was better demonstrated at a concentration of $20 \mu \mathrm{M}$, as the significant increase in sub-G0 populations $(\mathrm{p}<0.001)$ was accompanied by a significant loss of cells in SG2M phase $(p<0.01)$ in relation to untreated cells (Fig. 1 and 2B, respectively). 


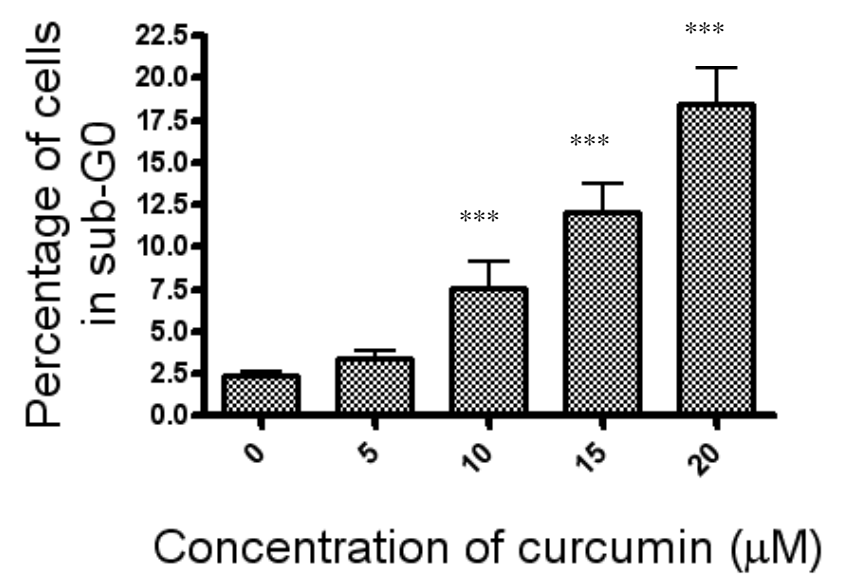

Figure 1 - Curcumin induces DNA fragmentation in human melanoma cells. SK-MEL-37 cells (3 X $10^{5}$ cells $/ \mathrm{mL}$ ) were treated with curcumin at the indicated concentrations for $24 \mathrm{~h}$. Asterisks represent significant difference between untreated and treated cells. Values are the mean \pm standard error of mean (mean \pm SE) of four independent experiments and data has been analyzed by ANOVA and Bonferroni's post test $(\mathrm{p}<0.001)$.

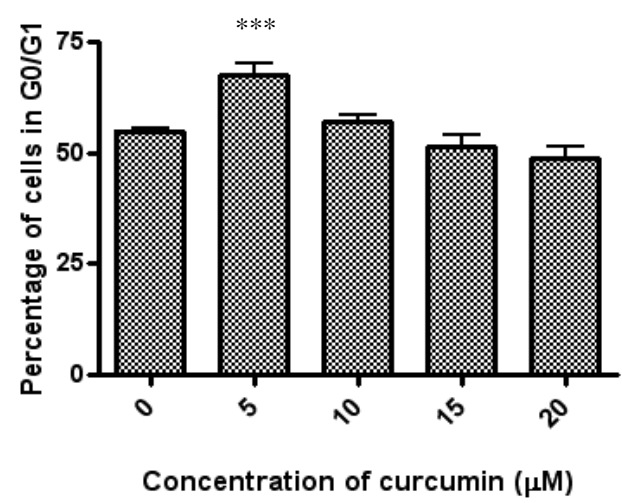

A

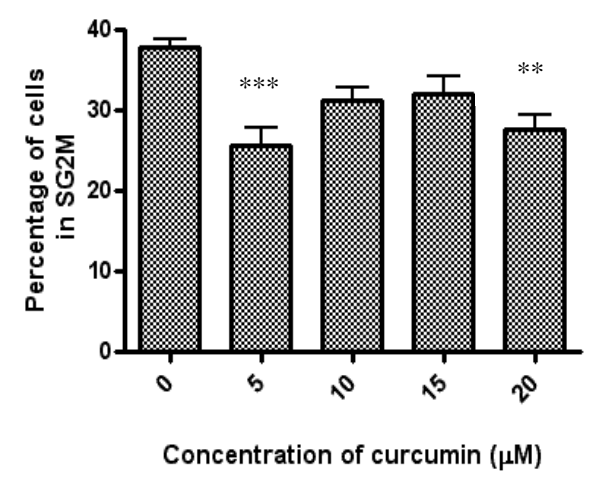

B

Figures 2 - A) Curcumin induced a G0/G1 cell cycle arrest. B) Curcumin decreased percentage of cells in SG2M phase. SK-MEL-37 cells (3 X $10^{5}$ cells $\left./ \mathrm{mL}\right)$ were treated with curcumin at the indicated concentrations for $24 \mathrm{~h}$. Asterisks represent significant difference between untreated and treated cells. Values are the mean (mean \pm SE) of four independent experiments and data had been analyzed by ANOVA and Bonferroni's post test $(* * \mathrm{p}<0.01 ; * * * \mathrm{p}<0.001)$.

\section{Morphological stimation of apoptosis}

To further characterize the apoptotic events morphologically, it was decided to analyze the results on cell cycle phases, by using fluorescence microscopy, transmission and scanning electron microscopy. Observations on the fluorescence microscope showed that the treatment with curcumin made the cells rounded (Fig. 3 B, C, D).
Still, the treatment with $15 \mu \mathrm{M}$ curcumin induced the formation of surface bebbling and fragmentation of the nucleus (Figs. 3 D, F). In contrast, untreated cells were fusiform in general and did not present morphological alterations (Fig. $3 \mathrm{~A})$. In addition, the fragmentation of the nucleus in cells treated with the concentrations of 10 and $15 \mu \mathrm{M}$ of curcumin were observed (Figs. 3 E, F). 
Cells stained with the cationic dye $\mathrm{JC}_{1}$ allowed for the determination of mitochondrial permeability transition, which was measured by flow cytometry. Intact mitochondria tended to concentrate $\mathrm{JC}_{1}$ dye, which emitted red fluorescence. The ratio of red: green fluorescence of SK-MEL-37 cells upon curcumin-treated was unchanged. Curcumin did not induce transmitochondrial potential alterations (data no shown).

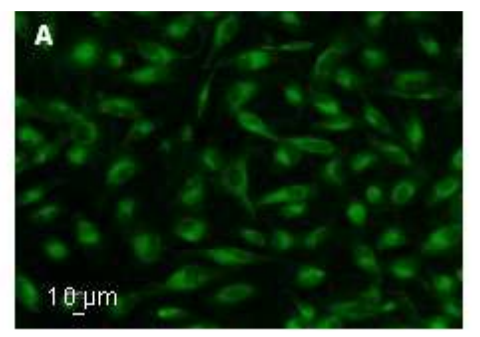

Ethanol $0,5 \%$

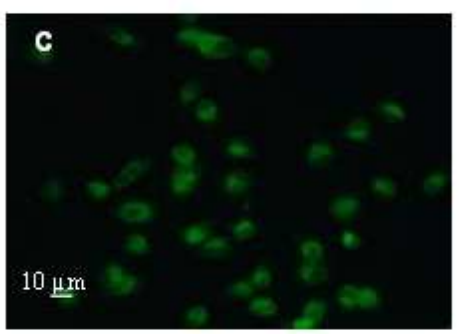

$10 \mu \mathrm{M}$

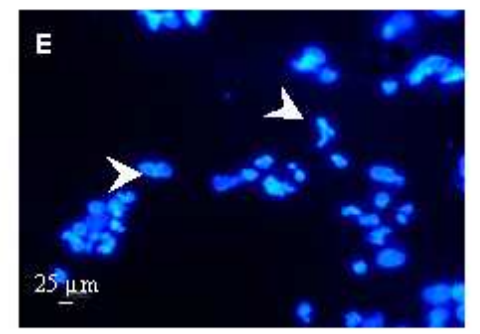

$10 \mu \mathrm{M}$

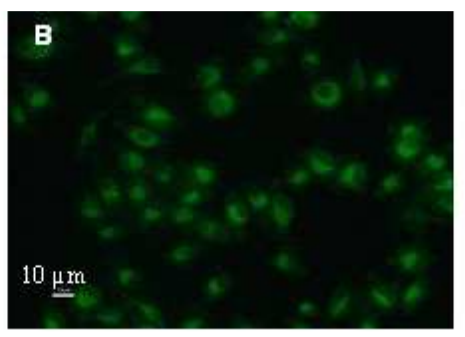

$5 \mu \mathrm{M}$

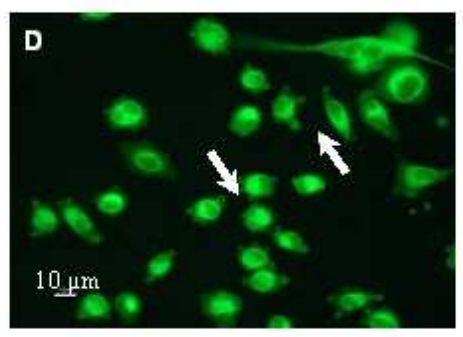

$15 \mu \mathrm{M}$

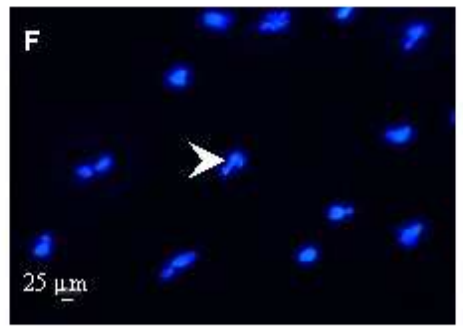

$15 \mu \mathrm{M}$

Figure 3 - Curcumin induced morphological alterations and nucleus fragmentation in human melanoma cells. Cells were washed and stained with $\mathrm{JC}_{1}(\mathrm{~A}-\mathrm{D})$ and DAPI (E-F) and analysed by fluorescence microscopy. Surface bebbling (arrows) and nucleus fragmentation (arrow heads) could be clearly seen at 10 and $15 \mu \mathrm{M}$ curcumin.

Observations in the transmission electron microscope showed ultra structural details of morphological changes of the process of death induced by curcumin. SK-MEL-37 cells presented projections of membrane surface (Fig. 4 A-F). According to the low percentage of apoptotic events detected by flow cytometry (Fig. 1), discrete chromatin segregation at the nucleus periphery was observed at $5 \mu \mathrm{M}$ curcumin for a 24 h-treatment (Fig. 4 D). Moreover at concentrations above $10 \mu \mathrm{M}$, apoptotic characteristic events as heterochromatin segregation at nucleus periphery and intense vacuolization could also be seen even at $6 \mathrm{~h}$ incubation (Figs. $4 \mathrm{E}-\mathrm{G}$ ). Apoptotic bodies were clearly evident after 24 h (Fig. 4 H).

Projections of membrane were observed in untreated cells (Fig. 5 A). Blebs at the surface of the plasma membrane were clearly seen by scanning electron microscope at 10,15 and $20 \mu \mathrm{M}$ curcumin, corroborating the results described above (Fig. 5, B-D). 

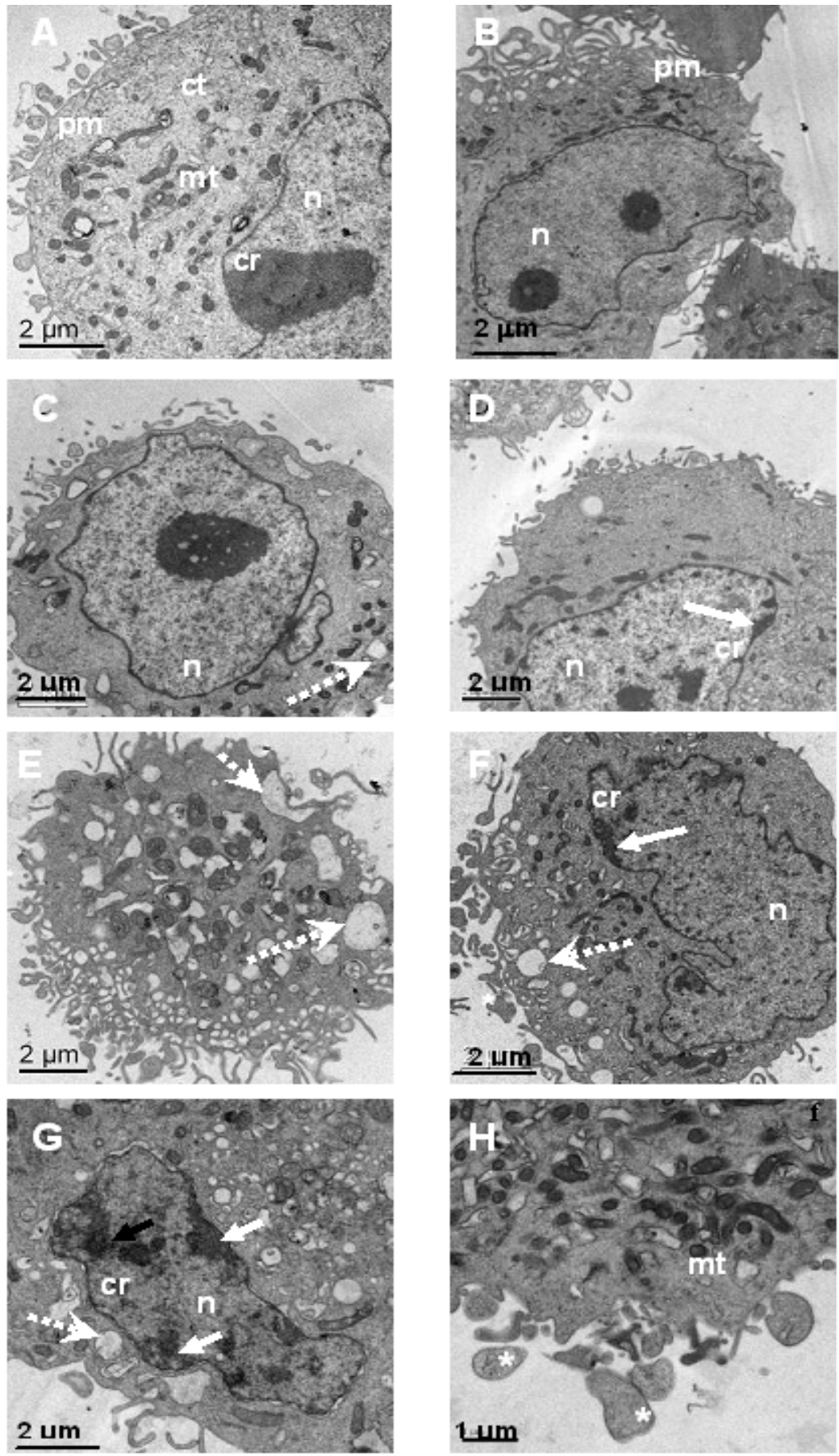

Figure 4 - Transmission electron micrographs of curcumin-treated human melanoma cells. Morphologic changes induced by curcumin such as segregation of the chromatin at the periphery of the nucleus (arrows), formation of vacuoles (hatched arrows) and apoptotic bodies (asterisk). Cells have been treated with $(0,5 \mu \mathrm{M}, 10 \mu \mathrm{M}, 15 \mu \mathrm{M})$ of curcumin for 6 hours (A, C, E) or 24 hours (B, D, F, G), respectively. Apoptotic bodies (asterisk) were observed after 24 hours treatment with $15 \mu \mathrm{M}$ curcumin (Fig. $4 \mathrm{H}$ ). Abbreviations: (n) nucleus, (cr) chromatin, (mt) mitochondria, (pm) plasma membrane. 

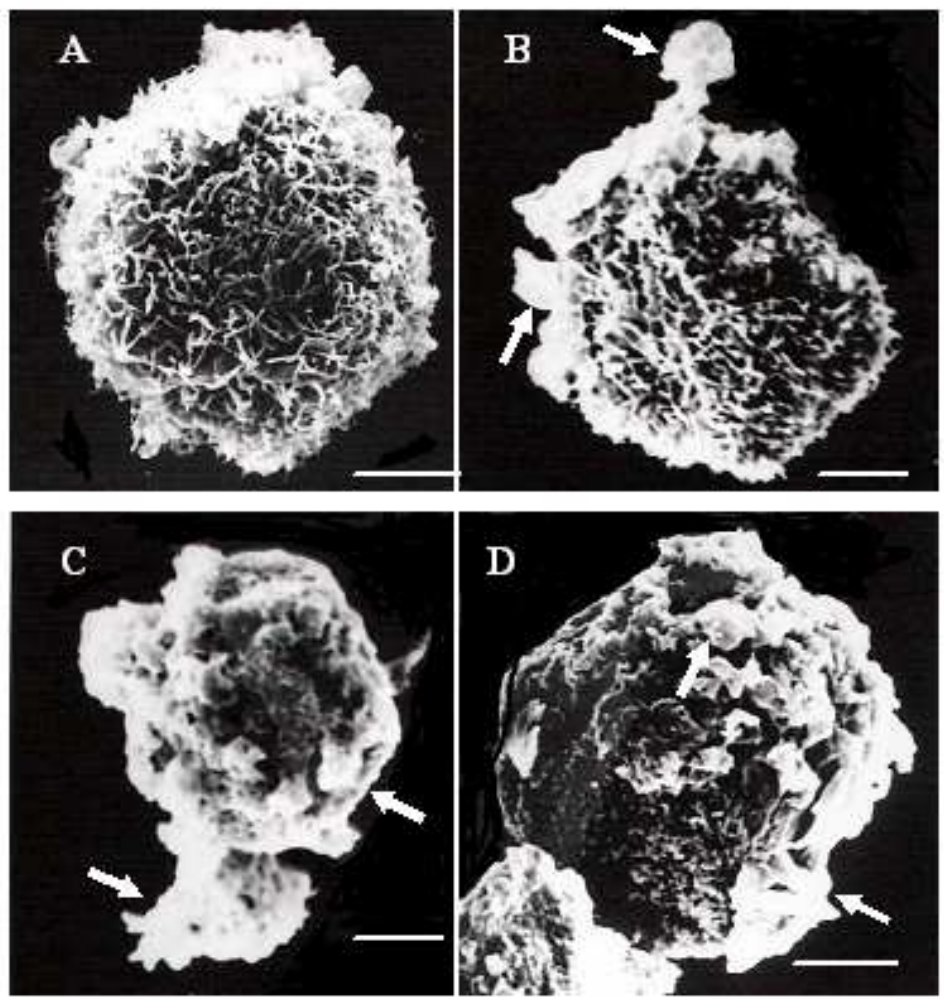

Figure 5 - Scanning electron micrographs of curcumin-treated human melanoma cells Membrane blebs (arrows) could be clearly seen in melanoma cells treated with $10 \mu \mathrm{M}, 15 \mu \mathrm{M}$ and $20 \mu \mathrm{M}$ of curcumin for 24 hours (B, C, D), respectively. (A) Untreated cells. Scale bars: (A-C) bar $=2 \mathrm{~mm}$; (D) bar $=3 \mathrm{~mm}$.

\section{DISCUSSION}

Plants used as food and in the folk and traditional medicine have been accepted currently as one of the main source of drug discovery and development. Indeed, the therapeutical potential of the curcumin as antitumor agent has been wide related in literature (Sharma et al., 2005; Maheswari et al., 2006; Thangapazhan et al., 2006). Studies have suggested that phenolic, methoxi and ketone groups in its chemical structure are very important for their biological activities (Joe et al., 2004). Moreover, diverse studies have demonstrated the inhibitory effect of curcumin in tumorigenesis through the induction of apoptosis in several tumor cell lines indicating a therapeutic potential for cancer treatment (Chen et al., 1998; Bush et al., 2001; Aggarwal et al., 2003; Odot et al., 2004; Zheng et al., 2004; Uddin et al., 2005; Shi et al., 2006; Su et al, 2006).

Studies on the growth of SK-MEL- 37 cells had demonstrated cytotoxic effects of curcumin in a concentration range of 5 to $20 \mu \mathrm{M}$ (Rabelo et al, 2002). In the present study, flow cytometry showed that $5 \mu \mathrm{M}$ curcumin induced a low percentage of apoptotic cells, although a significant increase in relation to control was observed in the cells treated with 10,15 and 20 $\mu \mathrm{M}$. These results were also confirmed by fluorescence microscopy, TEM and SEM.

It was shown that curcumin changed the profile of the cell cycle with an increase in G0/G1 population associated with a decrease in the SG2M cell population. Curiously, this effect was only observed at the low dose $(5 \mu \mathrm{M})$. By stalling the cells in G0/G1, additional time may be gained to repair any cellular damage. At high doses, irreparable damage induced apoptosis.

Up to now, G0/G1 cell cycle arrest has been reported mainly in normal curcumin-treated cells. Chen and Huang (1998) have demonstrated that curcumin treatment at $10^{-6}-10^{-5} \mathrm{M}$ induced $\mathrm{G} 0 / \mathrm{G} 1$ arrest in rat aortic smooth muscle cells. Human umbilical vein endothelial cells (Singh, et al., 
1996) and normal mammary epithelial cells (Choudhuri et al., 2005) are also arrested in G0/G1 phase.

Cancer cells, however, failed to be arrested in G0/G1 by curcumin. Curcumin induced G2/M cell cycle arrest has been described as leading to apoptosis. So, a variety of human carcinoma cells including breast (Simon et al. 1998), ovarian (Weir et al., 2007) and colon (Hanif et al., 1997; Chen et al., 1999) are all blocked in G2/M phase. Cultured human melanoma cells are also blocked in G2/M. It has been postulated that if cells have an overexpression of cyclin D1, curcumin fail to arrest these cancer cells and it allow them to pass into G2 phase and undergo apoptosis (Zheng et al., 2004; Choudhuri et al., 2005).

In the present study, it was found that $5 \mu \mathrm{M}$ curcumin could block the cells at G0/G1 phase and at higher concentrations curcumin could induce the apoptotic events in SK-MEL-37 melanoma cells. As mentioned above, numerous in vitro studies have demonstrated that curcumin exert apoptotic events in a variety of cancer cell lines, including melanoma. However, this has been the first time to detect a G0/G1 cell cycle arrest in human melanoma cells. This result suggested that the growth inhibitory effect of curcumin might be initiated by arresting the cells at G0/G1 phase before undergoing apoptosis.

Curcumin also induced morphological alterations such as blebbing of plasma membrane, formation of apoptotic bodies, chromatin condensation and segregation at nucleus periphery, in cells treated with 10-20 $\mu \mathrm{M}$. An intense accumulation of cytoplasmic vacuoles in cells treated with curcumin concentrations higher than $10 \mu \mathrm{M}$ was also observed. This was described by some authors as autophagic vacuolization and these studies have indicated that both autophagy and apoptosis were part of the programmed cellular death and both could be linked (Cho and Choi, 2002, Edinger and Thompson, 2004, Boya et al., 2005; Polo et al., 2005).

Present results did not demonstrate any alteration of the mitochondrial transmembrane potential at all tested concentrations, suggesting that the process of apoptosis, induced by curcumin, was not mediated by the mitochondria in SK-MEL-37 cells. These results agreed with the observations of Bush et al. (2001), showing a mitochondrialindependent pathway in eight human melanoma cell lines. However, these results might be cell- specific, since curcumin induced the apoptosis via mitochondria in many other types of cultured cancer cells (Anto et al., 2002; Woo et al., 2003; Hussain et al., 2006, Shankar et al., 2007).

The success of chemotherapeutic agents would be attributed to its potentialities in inducing the apoptosis in malignant cell populations (Syng-Ai et al., 2004). Considering that some chemoresistant melanoma cells might acquire sensitivity to chemotherapeutic agents by pre-treating with purine analogs (Zaffaroni et al., 1996), present results suggested a possible role of curcumin as a modulator of classical chemotherapeutical compounds as cisplatin derivatives or doxorubicin to treat the melanoma. Clinical treatment with low curcumin concentrations might arrest the cells at G0/G1, enhancing the efficacy of the chemotherapeutic agent.

Plants continue to be important for the development of new anti-cancer drugs. Considering that curcumin is a natural constituent of diet and demonstrate safe pharmacology, its therapeutic applications could become a promising tool. Therefore, it is important to promote the development of therapies that involve curcumin in the treatment of cancer, including melanoma.

\section{ACKNOWLEDGMENTS}

We are grateful to National Research Council (CNPq) and to Project and Study Financial (FINEP) for financial support. We also thank Paula Roberta Otaviano Soares and Larissa Matuda for assistance in many aspects of cell culture.

\section{RESUMO}

O melanoma é um tipo agressivo de câncer cujo tratamento culmina com o estabelecimento de resistência aos quimioterápicos empregados. Portanto, é importante o desenvolvimento de novos agentes farmacológicos que sejam menos tóxicos e que não provoquem quimiorresistência. As inúmeras propriedades terapêuticas da curcumina vêm sendo confirmadas através de estudos sobre o seu mecanismo de ação em células cultivadas. No presente estudo, empregamos células de melanoma humano da linhagem SK-MEL-37, que desenvolveram resistência in vitro à doxorubicina $\mathrm{e}$ 
cisplatina, drogas normalmente utilizadas na clínica. Investigamos o efeito da curcumina sobre o ciclo celular através de citometria de fluxo. Além disso, análises morfológicas e estruturais também foram realizadas. Os resultados demonstraram que o tratamento com uma concentração de $5 \square \mathrm{M}$ de curcumina provocou uma parada na subfase G0/G1. Além disso, observou-se um aumento dose-dependente na proporção de células hipodiplóides em sub-G0. Eventos apoptóticos típicos foram observados por microscopia de fluorescência, microscopia eletrônica de transmissão e microscopia eletrônica de varredura. Não foi detectada alteração no potencial de membrana mitocondrial. Os resultados indicam que futuros estudos poderão tornar possível a utilização da curcumina como um modulador para agentes quimioterápicos empregados na clínica no tratamento do melanoma.

\section{REFERENCES}

Aggarwal, B. B., Kumar, A., Bharti, A. C. (2003), Anticancer potential of curcumin preclinic and clinical studies. Anticancer Res., 23, 363-398.

Anto, R.J., Mukhopadhyay A., Denning, K., Aggarwal, B.B. (2002), Curcumin (diferuloylmethane) induces apoptosis through activation of caspase-8, BID cleavage and cytochrome c release: its suppression by ectopic expression of Bcl-2 and Bcl-xl. Carcinogenesis, 23, 143-150.

Araújo, C. A. C., Leon, L. L. (2001), Biological Activities of Curcuma Longa L. Mem. Inst. Oswaldo Cruz, 96, 723-728.

Boya, P., Polo, R.-A. G., Casares, N., Perfettini, J-L., Dessen, P., Larochette, N., Métivier, D., Meley, D., Souquere, S., Yoshimori, T., Pierron, G., Codogno, P., Kroemer, G. (2005), Inhibition of Macroautophagy triggers apoptosis. Mol. Cell. Biol., 25, 1025-1040.

Bush, J. A., Cheung, K-J. J, Li, G. (2001), Curcumin induces apoptosis in human melanoma cells through a Fas receptor/caspase-8 pathway independent of p53. Exp. Cell. Res., 271, 305-314.

Chen, H.-W., Huang, H.-C. (1998), Effect of curcumin on cell cycle progression and apoptosis in vascular smooth muscle cells. Br. J. Pharmacol., 124, 10291040.

Chen, H., Zhang, Z.-S., Zhang, Y.-L., Zhou, K.-Y. (1999), Curcumin inhibits cell proliferation by interfering with the cell cycle and inducing apoptosis in colon carcinoma cells. Anticancer Res., 19, 36753680 .
Cho, S.-G., Choi, E.J. (2002), Apoptotic signaling Pathways: Caspases and Stress-Activated Protein Kinases. Biochem. Mol. Biol., 35, 24-27.

Choudhuri, T., Pal, S., Das, T, Sa, G. (2005), Curcumin selectively induces apoptosis in deregulated cyclin D1-expressed cells at G2 phase of cell cycle in a p53dependent manner. J. Biol. Chem., 280, 20.05920.068.

Edinger, A. L., Thompson, C. B. (2004), Death by design: apoptosis, necrosis and autophagy. Curr. Opin. Cell. Biol., 16, 663-669.

Gray-Schopfer V., Wellbrock. C., Marais, R. (2007), Melanoma biology and new targeted therapy. Nature, 445, 851-857

Hanif, R., Qiao, L., Shiff, S.J., Rigas, B. (1997), Curcumin, a natural plant phenolic food additive, inhibits cell proliferation and induces cell cycle changes in colon adenocarcinoma cell lines by a prostaglandin-independent pathway. J. Lab. Clinic. Med., 130, 576-584

Hussain, A.R., Al-Rasheed, M., Manogaran, P.S., AlHussein, K.A., Platanias, L.C., Al Kuraya, K., Uddin. S., (2006), Curcumin induces apoptosis via inhibition of PI3'-kinase/AKT pathway in acute $\mathrm{T}$ cell leukemias. Apoptosis, 11, 245-254.

Joe, B., Viljaykumar, Lokesh, R. B. (2004), Biological properties of curcumin-cellular and molecular mechanisms of action. Crit. Rev. Food Sci. Nutr., 44, 97-111.

Maheshwari, R. K., Singh, A. K., Gaddipati, J., Srimal, R, C. (2006), Multiple biological activities of curcumin: a short review. Life Sciences, 78, 20812087.

Mans, D. R. A., Rocha, A. B., Shwartsmann, G. (2000), Anti-cancer drug discovery and development in Brazil: targeted plant collection as rational strategy to acquire candidate anti-cancer compounds. Oncologist, 5, 185-198.

Markovic S. N., Erickson L. A., Rao R. D., Weenig R. H., Pockaj B. A., Bardia A., Vachon C. M., Schild S. E., McWilliams R. R., Hand J. L., Laman S. D., Kottschade L. A., Maples W. J., Pittelkow M. R., Pulido J. S., Cameron J. D., Creagan E. T. (2007). Malignant melanoma in the 21st century, part 1: epidemiology, risk factors, screening, prevention, and diagnosis. Mayo Clin. Proc., 82, 364-380.

Odot, J. Albert, P., Carlier, M., Devy, J., Madoulet, C. (2004), In vitro and in vivo anti-tumoral effect of curcumin against melanoma cells. Int. J. Cancer, 111, 381-387.

Polo, R.-A. G., Boya, P., Pauleau, A-L., Jalil, A., Larocchette, N., Souquére, S., Eskelinen, E-L., Pierron, G., Saftig, P., Kroemer, G. (2005), The apoptosis/autophagy paradox: autophagic vacuolization before apoptotic death. J. Cell. Sci., 118, 3091-3102. 
Rabelo, A. S., Bretas, M. L., Guillo, L. A. (2002), Ensaio da citotoxicidade da curcumina. Paper presented at VI Reunião Regional da SBBq. Anais eletrônicos da VI Reunião Regional da SBBq (CDROM), Fortaleza, Brazil.

Shankar, S., Srivastava, R.K. (2007), Involvement of Bcl-2 family members, phosphatidylinositol 3'kinase/AKT and mitochondrial p53 in curcumin (diferulolylmethane)-induced apoptosis in prostate cancer. Int. J. Oncol., 30, 905-918

Sharma, R. A., Gescher, A. J., Steward, G. W. P. (2005), Curcumin: the story so far. Eur. J. Cancer, 41, 1955-1968

Shi, M., Cai, Q., Yao, L., Mao, Y., Ming, Y., Ouyang, G. (2006), Antiproliferation and apoptosis induced by curcumin in human ovarian cancer cells. Cell. Biol. Int., 30, 221-226

Simon, A., Allais, D. P., Duroux, J. L., Basly, J. P. Fontanier, D. Delage, C. (1998), Inhibitory effect of curcuminoids on MCF-7 cell proliferation and structure-activity relationships. Cancer Lett., 129, 111-117

Singh, A.K., Sidhu, G.S., Deepa, T. Maheshwari, R.K. (1996), Curcumin inhibits the proliferation and cell cycle progression of human umbilical vein endothelial cell. Cancer Lett., 107, 109-115

Su, C. C., Lin, J. G., Li, T. M., Chung, J. G., Yang, J. S., IP, S. W., Lin, W. C., Chen, G. W. (2006), Curcumin-induced apoptosis of human colon cancer cells through the production of $\mathrm{ROS}, \mathrm{Ca} 2+$ and activation of caspase-3. Anticancer Res., 26, 43794389.

Syng-Ai, C. Kumari, A. L., Khar, A. (2004), Effect of curcumin on normal and tumor cells: Role of glutathione and bcl-2. Mol. Cancer. Ther., 3, 11011108 .
Thangapazham, R. L., Sharma, A., Maheshwari, R. K., 2006, Multiple molecular targets in cancer chemoprevention by curcumin. A. APS. J., 8, 443449.

Uddin, S., H., A. R., Manogaran, P. S., Ai-Hussein, K., Platanias, C. L., Gutierrez, M. I., Bhatia, K. G. (2005), Curcumin suppresses growth and induces apoptosis in primary effusion lymphoma. Oncogene 24, 7022-7030

Weir, N. M., Selvendiran, K., Kutala, V. K., Vishwanath, S., Rajaram, M., Tridandapani, S., Anants, S., Kuppusamy, P. (2007), Curcumin induces G2/M arrest and apoptosis in cisplatin-resistant Human Ovarian Cancer Cells by modulating Akt e p38 MAPK. Cancer Biol. Ther., 6, 178-184.

Woo. J.H., Kim, Y.H., Choi, Y.J., Kim, D.G., Lee, K.S., Bae, J.H., Min, D.S., Chang, J.S., Jeong, Y.J, Lee, Y.H., Park, J.W., Kwon, T.K. (2003), Molecular mechanisms of curcumin-induced cytotoxicity: induction of apoptosis through generation of reactive oxygen species, down-regulation of Bcl-XL and IAP,the release of cytochrome $\mathrm{c}$ and inhibition of Akt. Carcinogenesis, 24, 1199-1208.

Zaffaroni, N., Orlandi, L., Gornati, D., De Marco, C., Vaglini, M., Silvestrini, R. (1996), Fludarabine as a modulator of cisplatin activity in human tumour primary cultures and established cell lines. Eur. J. Cancer, 32 A, 1766-1773.

Zheng, M., Ekmekcioglu, S., Walch, T. E., Tang, C., Grimm, A. E. (2004), Inhibition of nuclear factor-kB and nitric oxide by curcumin induces $\mathrm{G} 2 / \mathrm{M}$ cell cycle arrest and apoptosis in human melanoma cells. Melanoma Res., 14, 165-171.

Received: January 23, 2008; Revised: July 24, 2008; Accepted: September 25, 2009. 